\title{
CITRAAN DALAM KUMPULAN PUISI SYAHADAT SENGGAMA KARYA ASRO AL MURTHAWY
}

\author{
Sujoko $^{1}$, Edy Pranata Nasution ${ }^{2}$ \\ Program Studi Pendidikan Bahasa dan Sastra Indonesia, \\ Fakultas Keguruan dan Ilmu Pendidikan, Universitas Batanghari, \\ Jambi
}

\author{
sujoko1987@yahoo.com \\ edybrabra@yahoo.com
}

\begin{abstract}
This research is aimed at describing imagery in the poetry collection Syahadat Senggama by Asro Al Murthawy so that readers know that imagery is an important part of poetry. Besides, this research is qualitative descriptive in a form of words or sentences which consist of kinds of imagery in the poetry collection Syahadat Senggama by Asro Al Murthawy. The data of this research is quotations of words or sentences which contain imagery and the source of the data is the poetry collection of Asro Al Murthawy entitled Syahadat Senggama. This poetry collection is the second edition which published in November 2016 and has 60 pages. The technique of collecting the data is read and notetaking technique. Based on the result of the research, it can be concluded that the collection of poetry in Syahadat Senggama Asro Al Murthawy used 7 kinds of imagery, they are; sight, hearing, touch, smell, taste, movement, and thought. From those 7 imageries, the most dominant imagery occured in the poetry is see imagery. While the least dominant is taste and smell imagery.
\end{abstract}

Keywords: poetry, imagery, Syahadat Senggama

\footnotetext{
${ }^{1}$ Dosen Program Studi Pendidikan Bahasa dan Sastra Indonesia, Fakultas Keguruan dan Ilmu Pendidikan, Universitas Batanghari, Jambi

${ }^{2}$ Mahasiswa Program Studi Pendidikan Bahasa dan Sastra Indonesia, Fakultas Keguruan dan Ilmu Pendidikan, Universitas Batanghari, Jambi
} 


\section{PENDAHULUAN}

Karya sastra merupakan salah satu dari karya seni yang dibangun berdasarkan daya khayal penyair. "Karya sastra adalah karya imajinatif, fiktif dan ungkapan ekspresi penyair" (Susanto, 2016: 6). Karya sastra yang bersifat tidak nyata disajikan penyair berdasarkan daya khayal yang dimilikinya, sehingga dalam menciptakan karya sastra penyair memiliki kreatifitas dalam berimajinasi.

Karya sastra mengandung nilai instrinsik yang dapat dijadikan pedoman dalam kehidupan manusia. "Karya sastra adalah tulisan atau karangan yang mengandung nilai-nilai kebaikan yang ditulis dengan bahasa yang indah" (Kosasih, 2012: 1). Kelahiran sebuah karya sastra bersumber dari kehidupan yang bertata nilai dan dapat memberi sumbangan bagi terbentuknya tata nilai dalam suatu masyarakatt (Rahima 2017:1). Keindahan karya sastra dihasilkan oleh pemikiran manusia yang imajinatif penuh dengan khayalan yang disesuaikan dengan realita kehidupan yang ada. Walaupun bersifat imajinatif namun karya sastra memiliki nilai-nilai kebaikan dan filosofi kehidupan di dalamnya.

Karya sastra merupakan suatu karya yang di dalamnya mengandung unsur keindahan. "Karya sastra adalah karya seni puitis" (Pradopo, 2017: 13). Artinya, karya sastra mengandung unsur keindahan yang dapat membangkitkan perasaan, menarik perhatian, dan menimbulkan tanggapan yang jelas saat pembaca membacanya.

Salah satu ragam karya sastra yang kaya akan maknanya adalah puisi. Sebuah puisi merupakan ungkapan perasaan, penghayatan kehidupan manusia yang diciptakan secara spontan oleh pengarang."Puisi adalah pengucapan dengan perasaan" (Jassin dalam Rokhmansyah, 2014: 14). Selain ungkapan perasaan puisi juga merupakan hasil penghayatan kehidupan manusia yang diciptakan dari pikiran penyair. Puisi termasuk kedalam karya sastra yang sangat indah dan bermakna dalam, dengan keindahannya karya sastra kerap menjadi media hiburan manusia. "Puisi adalah salah satu bentuk karya sastra yang diwujudkan dengan kata-kata indah dan bermakna dalam" (Wahyuni, 2014: 12). Puisi yang diciptakan penyair selain memiliki keestetikaan di dalam karyanya juga terdapat makna-makna yang dianggap dalam bahkan luas untuk diartikan.

Puisi merupakan rekaman pemikiran penyair. "Puisi itu merupakan rekaman dan interpretasi pengalaman manusia yang penting, diubah dalam wujud yang paling berkesan" (Pradopo, 2017: 7). Menurut Pradopo, puisi yang diciptakan penyair berdasarkan pengamatan yang direkam oleh pancaindra yang diubah kedalam kata-kata sehingga memiliki kesan saat membacanya.

Puisi juga merupakan salah satu jenis karya sastra yang dapat dikaji dari berbagai aspek, di antaranya puisi dapat dikaji dari struktur dan unsur-unsurnya, mengingat struktur puisi tersusun dari bermacam unsur dan sarana kepuitisannya. Dapat pula dikaji dari jenis atau ragamragamnya, mengingat bahwa ada ragam puisi. Puisi dapat dikaji dari tinjauan kesejarahannya, mengingat sepanjang zaman puisi yang ditulis penyair dari waktu ke waktu mengalami perubahan (Pradopo, 2017: 3). Sehingga seiring berjalannya waktu puisi selalu mengalami perubahan. Saat ini, puisi tidak hanya digunakan sebagai sarana penulisan, melainkan puisi juga digunakan untuk mengungkapkan keluh kesah yang dialami oleh penyair berdasarkan pengamatan yang dilakukan terhadap kehidupan manusia, alam dan Tuhan. Begitu juga dengan kumpulan puisi Syahadat Senggama karya Asro Al Murthawy. Kumpulan puisi tersebut diciptakan penyair berdasarkan pengamatan ataupun pengalaman yang dirasakan oleh penyair di lingkungan masyarakat.

Puisi Syahadat Senggama terdari dari batang tubuh yang tersusun dari 
stuktur fisik dan struktur batin. Tanpa adanya struktur tersebut, puisi tidak dapat mempesona para pembaca dengan keindahan yang dimilikinya. Kedua struktur tersebut juga memiliki unsur pembangun dan salah satu unsur pembangun puisi yang terkandung di dalam struktur fisik adalah citraan.

Citraan dalam puisi digunakan penyair untuk memperkuat gambaran pemikiran pembaca yang melibatkan pancaindera sehingga pembaca seolah-olah dapat turut melihat, mendengar, serta merasakan apa yang dirasakan oleh penyair. Akan tetapi berdasarkan pengamatan peneliti, masyarakat sekarang tidak lagi memiliki perasaan atau citraan terhadap kenyataan saat ini dengan benar. Seperti, ada telinga tetapi tidak ingin mendengar kebenaran, ada mata tetapi seolah-olah tidak melihatnya sehingga sering terbalik, yang salah terlihat benar dan yang benar terlihat salah. Berdasarkan fenomena yang terjadi di masyarakat sekarang itulah yang menyebabkan peneliti lebih tertarik meneliti tentang citraan dibandingkan unsur pembangun struktur fisik yang lainnya.

Citraan merupakan salah satu unsur yang digunakan dalam menciptakan sebuah karya sastra. Seorang sastrawan menggunakan citraan dalam puisi guna memperkuat gambaran pemikiran pembaca yang dituangkan dengan menggunakan kata-kata yang dapat merangsang daya khayal pembaca. Citraan dapat menimbulkan imajinasi pembaca. "Citraan merupakan kata atau susunan kata yang dapat menimbulkan khayalan atau imajinasi" (Kosasih, 2008: 33). Artinya, imajinasi yang dimiliki pembaca seolaholah dapat merangsang pemikirannya sehingga pembaca dapat merasakan, mendengar, atau melihat sesuatu yang diungkapkan oleh penyair.

Citraan merupakan sesuatu yang menimbulkan daya khayal pembaca. "Citraan (imagery) merupakan gambarangambaran angan dalam puisi yang ditimbulkan melalui kata-kata" (Pradopo dalam Wiyatmi, 2009: 68). Citraan yang digunakan dalam puisi dapat menimbulkan imajinasi melalui kata-kata yang yang dihasilkan oleh pancaindera.

Citraan atau pengimajian merupakan susunan kata berdasarkan apa yang dilihat, didengar, maupun dirasakan penyair dengan menggunakan pancaindra. "Pengimajian adalah susunan kata-kata yang dapat mengungkapkan pengalaman sensoris di mana pembaca seolah-olah dapat melihat, mendengar, merasakan seperti apa yang dilihat, didengar, dan dirasakan penyair dalam puisinya secara imajinatif melalui pengalaman dan rasa" (Rokhmansyah, 2014: 18). Artinya, citraan yang digunakan penyair di dalam puisi berfungsi sebagai gambaran agar pembaca dapat mendapatkan gambaran secara jelas mengenai apa yang penyair lihat, dengar, serta rasakan.

Citaan memiliki beberapa jenis. dalam kajian ini penentuan kriteria atau jenis citraan berdasarkan atas sumber indera yang menghasilkannya. Menurut Pradopo (2017: 82) citraan terbagi menjadi 7 jenis yaitu: 1) Citraan Penglihatan, 2) Citraan Pendengaran, 3) Citraan Gerak, 4) Citraan Perabaan, 5) Citraan Penciuman, 6) Citraan Pencecapan, 7) Citraan Pemikiran yang akan dijabarkan sebagai berikut.

1. Citraan Penglihatan

Citraan penglihatan merupakan citraan yang paling sering digunakan yang merangsang indra penglihatan. "Citraan penglihatan memberi rangsangan kepada indra penglihatan, hingga sering hal-hal yang tak terlihat seolah-olah terlihat" (Pradopo, 2017: 82). Sehingga pembaca atau pendengar seolah-olah turut melihat apa yang dilihat oleh penyair.

Citraan penglihatan terdapat dalam puisi yang diciptakan penyair. "Citraan penglihatan adalah citraan yang timbul oleh indra penglihatan" (Damayanti, 2013: 30). Citraan penglihatan dalam puisi 
timbul dikarenakan adanya kata-kata yang merangsang indra penglihatan.

\section{Citraan Pendengaran}

Selain citraan penglihatan, citraan pendengaran juga termasuk salah satu jenis citraan yang sering digunakan penyair di dalam puisi. "Citraan pendengaran adalah citraan yang dihasilkan dengan menyebutkan atau menguraikan bunyi suara" (Altenberd dalam Pradopo, 2017: 82). Citraan ini memberikan rangsangan kepada indera pendengar, sehingga katakata yang ditulis penyair seolah-olah mengeluarkan bunyi, dan pembaca dapat mengungkapkan bunyi yang tertulis dari puisi.

Citraan pendengaran menyebabkan pembaca seperti mendengar bunyi-bunyi. "Citraan pendengaran menyebabkan pembaca seperti mendengar sendiri apa yang dikemukakan penyair" (Rokhmansyah, 2014: 19). Suara dan bunyi yang dipergunakan tepat sekali untuk melukiskan hal-hal yang melibatkan indra pendengaran.

3. Citraan Gerak

Pradopo (2017: 87) menyatakan "Citraan gerak menggambarkan sesuatu yang sesungguhnya tidak bergerak, tetapi seolah-olah bergerak, ataupun gambaran gerak pada umumnya". Citraan ini dapat menyebabkan hidup dan gambaran menjadi dinamis.

Citraan gerak digunakan penyair dalam puisinya. "Citraan gerak merupakan citraan gerak tubuh atau otot yang menyebabkan kita merasakan atau melihat gerakan badan atau otot-otot tubuh" (Rokhmansyah, 2014: 19). Penyair menginginkan pembaca merasakan atau seolah-olah melihat pergerakan yang dilukiskan dalam puisi.

4. Citraan Perabaan

Damayanti (2013: 31) menyatakan "Citraan perabaan adalah citraan yang ditimbulkan atau berkaitan dengan kulit". Citraan ini seolah-olah membuat pembaca dapat merasakan melalui kulit mengenai sifat-sifat benda.

Citraan perabaan dapat dirasakan oleh alat rabaan pada manusia. Menurut Pradopo (2017: 83) citraan perabaan adalah "Citraan yang dapat dirasakan oleh indra peraba saat membacakan atau mendengarkan larik-larik puisi, sehingga penikmat dapat menemukan diksi yang dapat dirasakannya". Misalnya dari kata lembut, kasar, dan sebagainya pembaca seolah-olah turut merasakannya melalui indra peraba yang dimilikinya

Citraan perabaan dapat disebut imajinasi faktual. "imajinasi faktual atau citraan perabaan menyebabkan kita seperti merasakan dibagian kulit badan" (Rokhmansyah, 2014: 19). Citraan perabaan yang dirasakan dapat berupa rasa nyeri, rasa panas oleh tekanan udara atau oleh perubahan suhu udara.

5. Citraan Penciuman

Melalui indra penciuman yaitu hidung pembaca seolah-olah dapat mencium aroma. "Citraan penciuman adalah citraan yang dapat dirasakan melalui indra penciuman atau yang berhubungan dengan gambaran yang dihasilakn oleh indra penciuman" (Pradopo, 2017: 82). Sehingga pembaca dapat mencium aroma yang dilukiskan penyair dalam puisi yang diciptakannya.

Citraan penciuman dalam puisi digunakan agar pembaca dapat turut mencium bau. "Citraan penciuman adalah pelukisan imajinasi penciuman atau pembawaan dengan membaca atau mendengar kata-kata tertentu seperti mencium bau" (Damayanti, 2013: 32).

6. Citraan Pencecapan

Citraan pencecapan menggunakan pancaindra seperti lidah. Damayanti (2013: 33) menyatakan bahwa "Citraan pencecapan adalah pelukisan imajinasi pencecapan". Citraan ini menyebankan pembaca dapat merasakan sesuatu yang menimbulkan rasa yang dapat dirasakan oleh lidah. 
Citraan pencecapan digunakan dalam puisi seakan-akan pembaca dapat mencicipi suatu benda. "Citraan pencecapan adalah citraan yang muncul dari puisi sehingga kita seakan-akan mencicipi suatu benda yang menimbulkan rasa pahit, manis, asam, dan lain-lain" (Pradopo, 2017: 82). Dengan menbaca atau mendengar kata atau kalimat tertentu kita dapat mencicipi suatu benda.

\section{Citraan Pemikiran}

$$
\text { Menurut Pradopo (2017: 82) }
$$

"Citraan pemikiran adalah citraan yang dihasilkan oleh citraan pemikiran seolaholah kita juga berfikir". Citraan pemikiran muncul dibenak pembaca karena merangsang pikiran untuk membayangkan bagaimana kata-kata seperti pesona dapat muncul. Padahal, pesona itu abstrak dan tidak dapat dilihat mata.

Penelitian ini memiliki Fokus pada analisis jenis citraan pendengaran dan citraan perabaan dalam kumpulan puisi Syahadat Senggama karya Asro Al Murthawy. Dan pertanyaan dalam penelitian ini adalah bagaimanakah penggunaan citraan pendengaran dan citraan perabaan dalam kumpulan puisi Syahadat Senggama karya Asro Al Murthawy?

Adapun tujuan penelitian secara umum digunakan untuk meningkatkan daya nalar dan untuk mencari jawaban permasalahan melalui penelitian. Berdasarkan fokus permasalahan dan pertanyaan penelitian yang telah dipaparkan, maka tujuan penelitian ini adalah untuk mendeskripsikan citraan pendengaran dan citraan perabaan dalam kumpulan puisi Syahadat Senggama karya Asro Al Murthawy.

\section{METODE PENELITIAN}

Dalam suatu penelitian sastra ada beberapa pendekatan dalam menganalisis nya. Perbedaan pendekatan inilah yang kemudian memunculkan adanya berbagai jenis penelitian sastra (Rahima, 2017:116). Jenis yang digunakan pada penelitian ini bersifat deskriptif kualitatif. Menurut Nawawi (dalam Siswantoro, 2010: 58) "Jenis deskriptif dapat diartikan sebagai prosedur pemecahan masalah yang diselidiki dengan menggambarkan atau melukiskan keadaan subjek dan objek penelitian (novel, drama, cerita pendek, puisi) pada saat sekarang berdasarkan fakta-fakta yang tampak atau sebagaiman adanya". Artinya seorang peneliti sastra dituntut mengungkapkan fakta yang tampak dengan cara mendeskripsikan kumpulan puisi Syahadat Senggama karya Asro Al Murthawy, kemudian datanya akan disajikan dalam bentuk kata-kata atau kalimat berdasarkan fakta-fakta yang ada.

Setiap penelitian memiliki data dan sumber data. Berikut data dan sumber data yang digunakan dalam penelitian ini. Data merupakan sumber terpenting dalam suatu penelitian yang disajikan sebagai bahan analisis peneliti. "Data adalah sumber informasi yang akan diseleksi sebagai bahan analisi" (Siswantoro, 2010: 70). Dalam penelitian ini data yang peneliti gunakan berhubungan langsung dengan jenis-jenis citraan dalam kumpulan puisi Syahadat Senggama karya Asro Al Murthawy melalui ungkapan-ungkapan, kata-kata serta kalimat yang terdapat di dalamnya, sedangkan sumber data penelitian ini adalah buku kumpulan puisi Syahadat Senggama karya Asro Al Murthawy yang merupakan cetakan kedua pada bulan November 2016 dan memiliki 60 halaman.

Teknik pengumpulan data dalam penelitian ini dilakukan cara sebagai berikut:

1. Peneliti membaca dengan teliti dan berulang-ulang. Serta memahami isi dari kumpulan puisi Syahadat Senggama karya Asro Al Murthawy.

2. Peneliti menandai dengan menggunakan penanda atau stabilo pada bagian kata-kata atau kaliamat yang termasuk ke dalam citraan.

3. Peneliti mencatat data yang termasuk ke dalam citraan. 
4. Peneliti mengklasifikasikan bagianbagian tentang citraan yang telah ditandai sebelumnya.

Analisis data dilakukan setelah datadata terkumpul secara keseluruhan, kemudian peneliti menyusun kesimpulan terhadap masing-masing masalah dalam penelitian ini berupa kata-kata atau kalimat yang terdapat dalam antologi puisi.

Langkah-langkah analisis data dilakukan sebagai berikut.

1. Data yang telah dikelompokkan ke dalam teknik pengumpulan data di atas kemudian ditabulasikan ke dalam tabel tabulasi data.

2. Menganalisis data sesuai dengan aspek citraan yang terdapat pada 30 puisi dalam kumpulan puisi Syahadat Senggama Asro Al Murthawy.

3. Mendeskripsikan data yang telah yang telah ditabulasikan secara jelas, agar data tersebut dapat dimengerti pembaca sesuai dengan data yang telah disiapkan.

4. Melakukan keabsahan data dengan tiga cara yakni: a) menkonsultasikan data dengan ahli. Dalam hal ini peneliti menjadikan dosen pembimbing sebagai ahli; b) mencocokan data dengan teori yang dijadikan sebagai landasan penelitian ini; c) menyesuaikan data ini dengan metode penelitian yang dipakai.

5. Merumuskan kesimpulan data yang sudah dianalisis dan dideskripsikan.

\section{HASIL DAN PEMBAHASAN}

Hasil penelitian dan pembahasan objek penelitian ini disatukan dalam satu pemaparan. Secara berurut dalam uraian berikut ini yang membahas dan menganalisis tentang jenis-jenis citraan puisi dalam kumpulan puisi Syahadat Senggama karya Asro Al Murthawy, yang meliputi citraan pendengaran dan citraan perabaan.

Citraan puisi dalam kumpulan puisi Syahadat Senggama karya Asro Al Murthawy dijelaskan sebagai berikut.
Berdasarkan hasil analisis, ditemukan sebanyak 10 citraan pendengaran yaitu dua citraan pendengaran dalam puisi Translasi Rindu, satu citraan pendengaran dalam puisi Lelaki yang Ingin Menggambar Darah; dua citraan pendengaran dalam puisi Mari Syahadat Senggama; lima citraan pendengaran dalam puisi Bait Sajak yang Hilang. Sehingga diketahui dari 6 puisi dalam kumpulan puisi Syahadat Senggama karya Asro Al Murthawy hanya ada 4 puisi yang menggunakan citraan pendengaran. Citraan pendengaran juga sangat sering dipergunakan oleh penyair. Jadi, citraan pendengaran ini dihasilkan oleh bunyibunyi atau suara. Citraan pendengaran dalam kumpulan puisi Syahadat Senggama karya Asro Al Murthawy terdapat pada kutipan, sebagai berikut:

Kutipan 1

"Pada elaan nafas yang terburu" (Translasi Rindu, hal 3).

Pada penggalan puisi tersebut, penyair menggambarkan citraan pendengaran dengan kata elaan nafas yang akan dibaca atau didengar oleh penikmat puisi tersebut seolah-olah mendengar suara elaan nafas seseorang yang terlalu bernafsu. Sehingga siapapun yang membaca atau mendengarnya akan membayangkan hal tersebut benar terjadi, maka dari itu termasuk ke dalam citraan pendengaran. Berdasarkan hasil analisis di atas, dapat peneliti simpulkan bahwa kajian tersebut sesuai dengan apa yang dikemukakan oleh Damayanti (2013: 83) yakni kata-kata itu seolah-olah mengeluarkan bunyi, dan pembaca dapat mengungkapkan bunyi. Hal tersebut dipertegas oleh Rokhmansyah (2014: 19) yakni citraan pendengaran menyebabkan pembaca seperti mendengar sendiri apa yang dikemukakan penyair.

Kutipan 2 
"Wahai sampaikan pesan sinyal menjelma siul angin yang gaib" (Translasi Rindu, hal 3).

Pada penggalan puisi di atas, penyair menggambarkan citraan pendengaran dengan menggunakan kata siul. Kata tersebut digambarkan oleh penyair agar pembaca mendengar suara tiruan bunyi angin yang seolah-olah memang ada. Berdasarkan hasil analisis di atas, dapat peneliti simpulkan bahwa kajian tersebut sesuai dengan apa yang dikemukakan oleh Pradopo (2017: 82) yakni citraan pendengaran merupakan citraan yang dihasilkan dengan menyebutkan atau menguraikan bunyi suara. Rokhmansyah (2014: 19) mempertegas hal terebut dengan menyatakan bahwa citraan pendengaran menyebabkan pembaca seperti mendengar sendiri apa yang dikemukakan penyair. Sehingga kata siul merupakan jenis citraan pendengaran.

Kutipan 3

"Aku ingin memberi warna semesta, teriakmu" (Lelaki yang Ingin Menggambar Darah, hal 17).

Pada kutipan puisi tersebut, citraan pendengaran terdapat pada kalimat aku ingin memberi warna semesta. Penyair menggambarkan kalimat tersebut agar pembaca seolah-olah dapat mendengar teriakkan yang dikeluarkannya yakni ia ingin memberi kesan yang yang berbeda untuk orang-orang di sekitar penyair. Sehingga ketika membaca kalimat tersebut pembaca seakan mendengar triakan penyair. Berdasarkan hasil analisis di atas, dapat peneliti simpulkan bahwa kajian tersebut sesuai dengan apa yang dikemukakan oleh Rokhmansyah (2014: 19) bahwa citraan pendengaran menyebabkan pembaca seperti mendengar sendiri apa yang dikemukakan penyair. Damayanti (2013: 83) mempertegas hal tersebut dengan menyatakan bahwa katakata itu seolah-olah mengeluarkan bunyi, dan pembaca dapat mengungkapkan bunyi.
Selanjutnya berdasarkan analisis data diketahui bahwa pada citraan perabaan, ditemukan empat citraan perabaan dalam 6 puisi dalam kumpulan puisi Syahadat Senggama karya Asro Al Murthawy. Puisi-puisi tersebut antara lain puisi Diambang Waktu Kuperam Rindu terdapat satu citraan, puisi Bait Sajak yang Hilang terdapat tiga citraan.

Citraan perabaan ini melibatkan indra peraba (kulit). "Citraan yang dapat dirasakan oleh indra peraba saat membacakan atau mendengarkan lariklarik puisi, sehingga penikmat dapat menemukan diksi yang dapat dirasakannya misalnya dingin, panas, lembut, kasar, dan sebagainya" (Pradopo, 2017: 84). Citraan perabaan dalam kumpulan puisi Syahadat Senggama karya Asro Al Murthawy terdapat pada kutipan, sebagai berikut.

\section{Kutipan 4}

"Hujan mengubah asin keringat dan perih air mata sejuk" (Diambang Waktu Kuperam Rindu, hal 8).

Pada penggalan bait puisi tersebut, penyair menggambarkan citraan perabaan dengan kata perih. Perih itu berarti rasa pedih yang dirasakan oleh kulit. Penyair seolah-olah ingin pembaca merasakan pedih saat membaca kata tersebut. Maka dari itu, berdasarkan hasil analisis di atas dapat peneliti simpulkan bahwa kajian tersebut sesuai dengan apa yang dikemukakan oleh Pradopo (2017: 84) yakni citraan yang dapat dirasakan oleh indra peraba saat membacakan atau mendengarkan larik-larik puisi, sehingga penikmat dapat menemukan diksi yang dapat dirasakannya. Hal tersebut diperkuat oleh Damayanti (2013: 31) yakni citraan ini seolah-olah membuat pembaca dapat merasakan melalui kulit mengenai sifatsifat benda.

Kutipan 5

"Aku tergugu menggigil melingkari kota mencari jejak bait" (Bait Sajak yang Hilang, hal 36). 
Pada bait puisi di atas, mengigil merupakan citraan perabaan. Penyair menggambarkan kata menggigil sebagai keadaan udara yang terasa sangat dingin dikulit. Sehingga saat membaca kata tersebut pembaca atau pendengar dapat merasakan seolah-olah suhu udara tersebut memang ada. Berdasarkan hasil analisis di atas dapat peneliti simpulkan bahwa kajian tersebut sesuai dengan apa yang dikemukakan oleh Pradopo (2017: 84) yakni citraan yang dapat dirasakan oleh indra peraba saat membacakan atau mendengarkan larik-larik puisi, sehingga penikmat dapat menemukan diksi yang dapat dirasakannya. Hal tersebut dipertegas oleh Rokhmansyah (2014: 19) yang menyatakan citraan perabaan memyebabkan kita seperti merasakan di bagian kulit rasa nyeri, dingin, panas oleh tekanan udara atau oleh perubahan suhu.

Kutipan 6

"Melingkar ringkus dingin kota" (Bait Sajak yang Hilang, hal 36).

Pada penggalan bait puisi tersebut, penyair menggambarkan citraan perabaan dengan kata dingin. Rasa dingin yang digambarkan penyair itu adalah citraan perabaan. Kata dingin merupakan kata yang paling sering digunakan penyair dalam puisi guna menunjukkan apa yang ia rasakan saat itu. Berdasarkan hasil analisis di atas dapat peneliti simpulkan bahwa kajian tersebut sesuai dengan apa yang dikemukakan oleh Rokhmansyah (2014: 19) yang menyatakan citraan perabaan menyebabkan kita seperti merasakan di bagian kulit rasa nyeri, dingin, panas oleh tekanan udara atau oleh perubahan suhu. Pradopo (2017: 84) turut mempertegas hal tersebut dengan menyatakan bahwa citraan perabaan dapat dirasakan oleh indra peraba saat membacakan atau mendengarkan larik-larik puisi, sehingga penikmat dapat menemukan diksi yang dapat dirasakannya.

\section{SIMPULAN}

Berdasarkan hasil analisis terhadap kumpulan puisi Syahadat Senggama karya Asro Al Murthawy, ditemukan 42 jumlah kutipan. Dari 42 kutipan tersebut, ditemukan citraan pendengaran dan citraan perabaan. Berdasarkan kata atau kalimat yang digunakan penyair dalam puisi yang diciptakannya. 42 kutipan tersebut ditemukan dalam puisi Ranjang Pertempuran, puisi Diambang Waktu Kuperam Rindu, puisi Syahadat Senggama, puisi Bait sajak yang Hilang, puisi Translasi Rindu, dan puisi Lelaki yang Ingin Menggambar Darah. Selain itu, kumpulan puisi tersebut diciptakan penyair berdasarkan pengamatan ataupun pengalaman yang dirasakan oleh penyair di lingkungan masyarakat.

\section{DAFTAR PUSTAKA}

Damayanti, D. (2013). Buku Pintar Sastra Indonesia; Puisi, Sajak, Syair, Pantun, dan Majas. Yogyakarta: Araska

Kosasih, E. (2008). Apresiasi Sastra Indonesia. Bandung: Nobel Edumedia

Kosasih, E. (2012). Dasar-Dasar Keterampilan Bersastra. Yogyakarta: CV. Yarma Widya

Pradopo, Rachmat Djoko. (2017). Pengkajian Puisi. Yogyakarta: Gajah Mada University Press

Rahima, A. (2017). Literature Reception (a Conceptual Overview). Jurnal Ilmiah Dikdaya, 6(1), 1-16.

Rokhmansyah, Alfian. (2014). Studi dan Pengkajian Sastra; Perkenalan Awal Terhadap Ilmu Sastra. Yogyakarta: Graha Ilmu

Siswantoro. (2010). Metode Penelitian Sastra. Yogyakarta: Pustaka Pelajar

Wahyuni, Risti. (2014). Kitap Lengkap Puisi Prosa dan Pantun Lama. Yogyakarta: Saufa

Wiyatmi. (2009). Pengantar Kajian Sastra. Yogyakarta: Pustaka Book Publish. 